\title{
PRESIDENTIAL THRESHOLD TERHADAP PEMILIHAN PRESIDEN DAN WAKIL PRESIDEN REPUBLIK INDONESIA DALAM SISTEM KETATANEGARAAN
}

\author{
Putri Lina Wahyuni, Elidar Sari, Mukhlis \\ Fakultas Hukum Program Studi Hukum Unimal \\ Komplek Kampus Bukit Indah, Jl. Jawa - Blang Pulo Kecamatan Muara Satu \\ P.O.Box 141 Lhokseumawe Mobile 082331239196 Faks. (0645) 40209
}

\begin{abstract}
The holding of elections simultaneously raises implications for the mechanism of general elections the President and Vice-President, especially in terms of the implementation of the presidential threshold. After the decision of the Constitutional Court (MK) number 14/PUU$\mathrm{XI} / 2013$, which mandates the simultaneous elections raises the pros and cons about setting the presidential threshold. In the perspective of the Constitution, using or not using the presidential threshold indeed does not conflict with the Constitution, because the presidential threshold is the policy of the law that are open from forming laws.

The purpose of this paper is to study the presidential threshold in conjunction with a Simultaneous Election in 2019. The method of approach in this research is normative juridical with examines the problems that arise in terms of the law. The presidential threshold has been twice used in the election, the results show evidence that the presidential threshold is very positive become a tool of initial selection of candidates for President and Vice-President.

The use of the presidential threshold in the elections in Indonesia was initially set in the 1945 Constitution (UUD 1945) stated in article 6A, and then further regulated in Legislation Number 23/2003 about General Election of President and Vice-President, then amended by Lagislation Number 42/2008 on General Election of President and Vice-President are next rearranged in Lagislation Number 7/2017 about General Elections. In the implementation of the presidential threshold is not necessarily only a positive impact, but there are also negative impacts such as the presence of new parties that have passed verification and are expressed as participants of the election by the Election Commission (KPU) in 2019 it does not have political rights in candidates for President and Vice-President, and the presence of Indonesian citizens who feel maimed political rights for which he choose in the 2014 election not necessarily be the choice in the elections 2019 or the candidate would they choose is canceled forward because the rules of the presidentila threshold. With keep the enactment of the rule threshold in the 2019 elections expected legislators to rethink about the terms of the presidential threshold, especially in conjunction with simultaneous elections, taking into account the advantages and disadvantages in the application or removal of the presidential threshold, for the purpose to strengthen the presidential system in Indonesia.
\end{abstract}

Keywords :The Presidential Threshold, the verdict of the Constitutional Court, Simultaneous Elections

\section{Abstrak}

Penyelenggaraan pemilihan umum secara serentak memunculkan implikasi terhadap mekanisme penyelenggaraan pemilihan umum Presiden dan Wakil Presiden, khususnya dalam hal penerapan presidential threshold. Pasca putusan Mahkamah Konstitusi Nomor 14/PUU- 


\section{Jurnal Ilmiah Mahasiswa FAKULTAS HUKUM UNIMAL}

E-ISSN:

ISSN :

Volume 1 Nomor 1 Januari-April 2020 (halaman 38-58)

$\mathrm{XI} / 2013$ yang mengamanatkan pemilu serentak menimbulkan pro kontra tentang pengaturan presidential threshold. Dalam prespektif konstitusi, menggunakan atau tidak menggunakan presidential threshold sesungguhnya tidak bertentangan dengan konstitusi, karena presidential threshold merupakan kebijakan hukum terbuka dari pembentuk Undang-Undang.

Tujuan penulisan ini yaitu untuk menelaah Presidential threshold dalam hubungannya dengan pemilu serentak 2019. Metode pendekatan dalam penelitian ini yaitu yuridis normatif dengan mengkaji permasalahan-permasalahan yang muncul dari segi hukum. Presidential threshold telah dua kali digunakan dalam pemilu, hasilnya menunjukkan bukti bahwa presidential threshold sangat positif menjadi alat seleksi awal calon Presiden dan Wakil Presiden.

Pengaturan presidential threshold dalam pemilu di Indonesia awalnya diatur dalam UUD NRI 1945 dinyatakan dalam Pasal 6A, kemudian diatur lebih lanjut dalam UU Nomor 23 Tahun 2003 tentang Pemilihan Umum Presiden dan Wakil Presiden, kemudian diubah dengan UU Nomor 42 Tahun 2008 tentang Pemilihan Umum Presiden dan Wakil Presiden yang selanjutnya diatur kembali dalam UU Nomor 7 Tahun 2017 tentang Pemilihan Umum. Dalam pemberlakuan presidential threshold tidak serta merta hanya menimbulkan dampak positif saja, melainkan ada juga dampak negatifnya seperti adanya partai baru yang telah lulus verifikasi dan dinyatakan sebagai peserta pemilu oleh Komisi Pemilihan Umum tahun 2019 tidak mempunyai hak politik dalam pengusungan calon Presiden dan Wakil Presiden dan adanya Warga Negara Indonesia yang merasa dicederai hak politiknya sebab yang dipilih pada pemilu 2014 belum tentu menjadi pilihannya pada pemilu 2019 ataupun calon yang akan mereka pilih tersebut batal maju karena adanya aturan presidential threshold. Dengan tetap diberlakukannya aturan ambang batas di pemilu 2019 diharapkan pembentuk Undang-Undang memikirkan kembali tentang ketentuan presidential threshold terutama dalam hubungannya dengan pemilu serentak, dengan mempertimbangkan kelebihan dan kekurangan dalam penerapan atau penghapusan presidential threshold yang bertujuan untuk memperkuat sistem presidensial di Indonesia.

\section{Kata Kunci: Presidential Threshold, Putusan Mahkamah Konstitusi, Pemilu Serentak.}

\section{PENDAHULUAN}

Berdasarkan ketentuan Undang-Undang Dasar Negara Republik Indonesia Tahun 1945 (UUD NRI Tahun 1945) Pasal 1 ayat (1) menyatakan bahwa Indonesia merupakan Negara Kesatuan yang berbentuk Republik. Sebagai Negara Republik maka kekuasaan pemerintah di Indonesia dipimpin oleh seorang Presiden, yang diatur dalam UUD NRI Tahun 1945 pasal 4 Ayat (1) Presiden Republik Indonesia memegang kekuasaan pemerintahan menurut UndangUndang Dasar.

Pemilihan Umum (pemilu) merupakan instrumen penting dalam negara demokrasi dengan sistem perwakilan. Indonesia sebagai negara hukum dengan pemerintahan yang demokratis mengakui pemilu sebagai pilar penting demokrasi yang harus diselenggarakan secara demokratis. Mekanisme pemilihan Presiden dan Wakil Presiden diatur secara lebih rinci dalam Pasal 6A UUD 1945 sedangkan Indonesia telah mengatur perihal pelaksanaan pemilu yang termaktub dalam pasal 22E UUD NRI Tahun 1945.

Konsep pemerintahan demokrasi adalah pemerintahan dari rakyat, oleh rakyat dan untuk rakyat. Pasal 1 ayat (2) UUD NRI Tahun 1945 menegaskan bahwa kedaulatan berada di tangan rakyat dan dilaksanakan menurut Undang- Undang Dasar. Sebagai negara demokrasi, maka dapat dikatakan bahwa memilih dan dipilih dalam pemilu adalah deviasi dari kedaulatan rakyat yang merupakan bagian dari hak asasi setiap warga negara (Nur Hidayat Sardini, 2011). Oleh karena itu, lazimnya di negara- negara yang menamakan diri sebagai negara demokrasi 


\section{Jurnal Ilmiah Mahasiswa FAKULTAS HUKUM UNIMAL}

E-ISSN:

ISSN :

Volume 1 Nomor 1 Januari-April 2020 (halaman 38-58)

mentradisikan pemilu untuk memilih pejabat-pejabat publik di bidang legislatif dan eksekutif baik di pusat maupun di daerah (A. Mukthie Fadjar, 2009).

Teori demokrasi minimalis, sebagaimana dijelaskan oleh Joseph Shumpeter, menyebutkan bahwa pemilihan umum merupakan sebuah arena yang mewadahi kompetisi antara aktor-aktor politik yang meraih kekuasaan partisipasi politik rakyat untuk menentukan pilihan serta liberalisasi hak-hak sipil dan politik warga negara (P.Antonius Sitepu,2012). Sedangkan menurut A.S.S. Tambunan, pemilu merupakan sarana atas pelaksanaan kedaulatan rakyat pada hakekatnya merupakan pengakuan dan perwujudan dari pada hak-hak politik rakyat dan sekaligus merupakan pendelegasian hak-hak tersebut oleh rakyat kepada wakil-wakilnya untuk menjalankan pemerintahan (Titik Triwulan Tutik, 2011).

Kegiatan pemilu merupakan sarana penyaluran hak asasi warga negara yang prinsipil. Oleh karena itu, dalam rangka pelaksanaan hak asasi warga negara menjadi suatu keharusan bagi pemerintah untuk menjamin terselenggaranya pemilu sesuai dengan jadwal ketatanegaraan yang ditentukan (Jimly Asshiddiqie, 2010). Dalam sejarah ketatanegaraan Indonesia, pelaksanaan pemilu telah dimulai pertama kali tahun 1955 di era Orde Lama dan dilanjutkan di era Orde Baru di bawah kepemimpinan Presiden Soeharto pada tahun 1971, 1977, 1982, 1987, 1992 dan 1997. Kemudian di era Reformasi pemilu dilaksanakan kembali pada 7 Juni 1999 untuk menggantikan produk pemilu 1997 yang dianggap tidak dipercaya lagi oleh rakyat. Setelah tahun 1999 Indonesia kembali melaksanakan pemilu setiap lima tahun sekali secara langsung untuk memilih anggota DPR, DPD, DPRD, serta Presiden dan Wakil Presiden yang dilaksanakan pada tahun 2004, 2009 dan 2014.

Menurut ketentuan UUD NRI Tahun 1945, yang termasuk dalam pemilu adalah pemilihan anggota Dewan Perwakilan Rakyat (DPR), Dewan Perwakilan Daerah (DPD) (Republik Indonesia, Undang-undang Dasar Negara Republik Indonesia Tahun 1945) dan Dewan Perwakilan Rakyat Daerah (DPRD) (Republik Indonesia, Undang-undang Dasar Negara Republik Indonesia Tahun 1945) serta pemilihan Presiden dan Wakil Presiden. (Republik Indonesia, Undang-undang Dasar Negara Republik Indonesia Tahun 1945). Namun dalam praktiknya selama ini, pemilihan anggota DPR, DPD dan DPRD ditempatkan secara terpisah dengan pemilihan Presiden dan Wakil Presiden dalam rezim pemilu legislatif. Sedangkan pemilihan Presiden dan Wakil Presiden ditempatkan dan diselenggarakan secara tersendiri dalam rezim pemilihan Presiden dan Wakil Presiden (Janpatar Simamora,2014).

Setelah adanya Putusan Mahkamah Konstitusi Nomor 14/PUU-XI/2013 tentang Pengujian Undang-Undang Nomor 42 Tahun 2008 tentang Pemilihan Umum Presiden dan Wakil Presiden, lahir konsep pemilu serentak. Mahkamah Konstitusi dalam putusannya menyatakan bahwa penyelenggaraan pemilu legislatif dan pemilu Presiden dan Wakil Presiden diselenggarakan secara bersamaan yang berlaku pada pemilu 2019 dan pemilu seterusnya. (Republik Indonesia, "Putusan Mahkamah Konstitusi No. 14/PUU-XI/2013) Perlunya pemilu serentak merupakan hasil uji materi (judicial review) atas Undang-Undang No. 42 Tahun 2008 tentang Pemilihan Umum Presiden dan Wakil Presiden terhadap UUD NRI Tahun 1945. Untuk pengusungan calon legislatif maupun bakal calon Presiden dan Wakil Presiden, maka harus memenuhi pensyaratan perolehan kursi minimal. Hal ini kemudian disebut sebagai ambang batas perolehan suara atau yang lebih dikenal dengan istilah threshold.

Dalam Pemilu di Indonesia, kata threshold dijumpai dalam tiga kasus pengaturan sistem Pemilu. Pertama, electoral threshold tertuang dalam Pasal 39 UU Nomor 3 Tahun 1999 Tentang Pemilihan Umum. Ketentuan ini dicantumkan kembali pada Pasal 143 ayat (1) UU Nomor 12 Tahun 2003 tentang pemilu Anggota DPR, DPD, dan DPRD. Kedua, presidential threshold tertuang dalam Pasal 5 ayat (4) UU Nomor 23 Tahun 2003 tentang Pilpres, Pasal 9 UU Nomor 42 Tahun 2008 tentang Pemilu Pilpres dan kemudian diatur kembali dalam UU Nomor 7 Tahun 


\section{Jurnal Ilmiah Mahasiswa FAKULTAS HUKUM UNIMAL}

E-ISSN:

ISSN :

Volume 1 Nomor 1 Januari-April 2020 (halaman 38-58)

2017 tentang Pemilihan Umum. Ketiga, parliamentary treshold tertuang dalam Pasal 202 ayat (1) UU Nomor 10 Tahun 2008 tentang Pemilu. Saat Pemilihan Umum 2014, dalam Undang-Undang Nomor 8 Tahun 2012 tentang Pemilu Legislatif.

Mengenai pengaturan presidential threshold sulit diterima oleh sebagian Partai Politik karena membatasi dalam hal pengusungan bakal calon Presiden dan Wakil Presiden. Maka dari itu banyak pihak yang mengajukan gugatan ke Mahkamah Konstitusi (MK), baik itu orang pribadi maupun perwakilan partai. Dimana isi gugatan tersebut semuanya menuntut tentang pemberlakuan ambang batas/presidential threshold yang menimbulkan pelanggaran hak politik pribadi warga negara maupun partai poltik dan menuntut pernyataan bahwa pembuat UU telah salah membuat aturan lebih lanjut soal tata cara pelaksanaan pemilihan Presiden dan Wakil Presiden sebagaimana yang diamanatkan oleh pasal 6A UUD NRI 1945 dengan menambah syarat prseidential threshold.

Secara teoritis sulit untuk memahami atau men-justifikasi pemberlakuan ambang batas pencalonan Presiden dalam pemilu serentak, secara empirik juga sulit mencari contoh pemberlakuan ambang batas pencalonan Presiden di banyak sistem presidensial yang ada di dunia ini (Dyayadi Hanan Ph.D., 2017). Amerika serikat, dengan sistem presidensial yang paling mapan, tidak memiliki aturan ambang batas pencalonan Presiden. Negara-negara di Amerika Latin, yang kebanyakan menganut sistem presidensial multipartai seperti indonesia juga tidak memberlakukan ambang batas pencalonan Presiden dalam Pilpresnya. Umumnya Pilpres dan Pemilu legislatif di Amerika Latin juga berlangsung serentak.

Meski tidak berlaku ambang batas pencalonan Presiden, tidak mesti pasangan Capres dan Cawapres akan selalu banyak. Di Mexico pada tahun 2012, Pilpres hanya diikuti oleh 4 pasangan calon. Di Kolumbia pada tahun 2014 juga hanya diikuti 5 pasangan calon. Ada tidaknya ambang batas pencalonan Presiden tidak menjadi penentu pasti banyaknya jumlah kandidat, tapi juga faktor lain seperti pemilihan umum, popularitas petahana, dan banyak faktor lain. Seperti di Indonesia, sistem pemilihan umum Presiden di kebanyakan Amerika Latin adalah sistem dua putaran (majority run-off): pemenang harus memperoleh minimal lebih dari 50 persen suara atau diadakan putaran kedua yang diikuti oleh peserta dengan perolehan suara terbanyak pertama dan kedua. Umumnya pemilu legislatif dan eksekutif di Amerika Latin juga berlangsung serentak dan tidak ada pemberlakuan ambang batas pencalonan Presiden.

Putusan Mahkamah Konstitusi Nomor 14/PUU-XI/2013 menyatakan bahwa Pemilu Presiden dan Wakil Presiden harus dilaksanakan secara serentak dengan Pemilu Legislatif pada Tahun 2019, dijelaskan bahwa Pemilu legislatif yang selanjutnya disebut Pileg, sehingga dengan ketetapan itu, maka acuan perolehan kursi atau suara partai-partai adalah merujuk kepada hasil Pemilu 2014. Sedangkan dalam hasil Pileg 2014, tidak ada satupun partai yang memenuhi minimal ambang batas 20\% kursi DPR atau 25\% suara sah nasional. Berikut daftar hasil Pileg 2014 (Redaksi Editorial, 2017):

a. Partai Demokrasi Indonesia Perjuangan (PDIP) 109 kursi / 23.681.471(18,95\%) suara.

b. Partai Golongan Karya (Golkar) 91 kursi / 18.432.312 (14,75\%) suara.

c. Partai Gerakan Indonesia Raya (Gerindra) 73 kursi / $14.760 .371(11,81 \%)$ suara.

d. Partai Demokrat 61 kursi / 12.728 .913 (10,19\%) suara.

e. Partai Amanat Nasional (PAN) 49 kursi / 9.481 .621 (7,59\%) suara.

f. Partai Kebangkitan Bangsa (PKB) 47 kursi / 11.298.957 (9,04\%) suara.

Dengan melihat hasil perolehan suara partai-partai yang mengikuti Pileg 2014, maka dapat dipastikan partai-partai itu harus melakukan koalisi, membangun kekuatan dengan partai yang lainnya agar dapat mengusung calon Presiden dan Wakil Presiden. 
Jurnal Ilmiah Mahasiswa

FAKULTAS HUKUM UNIMAL
E-ISSN:

ISSN :

Volume 1 Nomor 1 Januari-April 2020 (halaman 38-58)

Dalam naskah akademik rancangan Undang-Undang Pemilihan Umum, dikatakan bahwa alasan diadakannya ambang batas, yang dalam hal ini presidential threshold, bertujuan untuk memperkuat sistem pemerintahan Presidensial atau membentuk sistem pemerintahan Presidensial yang efektif. Sebab Indonesia adalah negara yang menganut sistem pemerintahan Presidensial. Dengan tetap diberlakukannya aturan ambang batas di Pemilu 2019 diharapkan dapat semakin mengokohkan sistem Presidensial yang dianut Indonesia.

Pada awalnya pengaturan presidential threshold oleh pembentuk Undang- Undang adalah dalam rangka penguatan sistem presidensial (Sodikin,2014). Itu sebabnya pemilu legislatif didahulukan dari pada pemilu Presiden dan Wakil Presiden. Apabila presidential threshold ini dihubungkan dengan putusan Mahkamah Konstitusi No. 14/PUU-XI/2013 ini akan muncul persoalan, apakah pengaturan presidential threshold dalam Pasal 9 Undang-Undang Nomor 42 Tahun 2008 tentang Pemilu pilpres dan Undang-Undang Nomor 7 Tahun 2017 tentang Pemilu relevan diberlakukan dalam pemilu serentak 2019 ataukah perlu pengaturan baru yang menghilangkan mekanisme presidential threshold? hal inilah yang menarik untuk dikaji dari pemberlakuan presidential threshold dalam pemilu serentak 2019.

\section{METODE PENELITIAN}

Penelitian ini merupakan penelitian kualitatif, yaitu penelitian yang memusatkan penelitian pada prinsip umum yang menggambari perwujudan satuan-satuan gejala yang ada dalam kehidupan masyarakat, atau pola-pola dianalisis gejala-gejala sosial budaya dengan menggunakan kebudayaan dari masyarakat yang bersangkutan untuk memperoleh gambaran mengenai pola-pola yang berlaku (Burhan Ashshofa, 2010).

Metode pendekatan dalam penelitian ini adalah yuridis normatif (normative legal research), yaitu dengan mengkaji permasalahan-permasalahan yang muncul dari segi hukum dan sebenarnya berasal dari peraturan perundang- undangan yang berlaku, teori-teori hukum dan pandangan hukum sebagai dasar acuan (Ammiruddin, 2003). Pendekatan perundang-undangan dilakukan dengan menelaah semua undang-undang dan regulasi yang berhubungan dengan isu hukum yang sedang di teliti (Peter Ahmad Marzuki, 2009).

\section{PEMBAHASAN}

\section{Presidential Threshold Dalam Sistem Ketatanegaraan Indonesia}

Threshold adalah bahasa Inggris, yang diartikan ke dalam bahasa Indonesia dapat berarti ambang batas. Sedangkan di dalam Kamus Besar Bahasa Indonesia (KBBI), ambang batas diartikan sebagai; "tingkatan batas yang masih dapat diterima atau ditoleransi" (https://kbbi.kemendikbud.go.id,2017). Threshold atau ambang batas ini diadopsi dalam sistem pemilu, sebagai formulasi perhitungan suara dan kursi pada sistem perwakilan proporsional.

Sebenarnya threshold secara matematika selalu ada, sehingga rumus threshold itu disebut threshold tersembunyi atau ambang batas efektif. Para ahli memberikan rumusan terkait ambang batas efektif ini, yakni seperti: ambang batas adalah 100\% dibagi besaran daerah pemilihan ditambah satu (threshold $=100 \%$ :besaran daerah pemilihan +1 ), contoh, besaran daerah pemilihan adalah 19 kursi, maka ambang batasnya adalah 5 persen. Inilah yang disebut sebagai threshold.

Threshold bisa dipahami juga sebagai sistem perwakilan proporsional, angka dan proporsi minimum, dari jumlah pemilih untuk menjadi perwakilan/utusan di parlemen. Istilah threshold juga diistilahkan dengan minimum barrier (batas minimum). Istilah ini sering digunakan untuk mengatur ambang batas parlemen (parliamentary threshold) dan ambang batas presiden untuk bisa ikut Pemilu (presidential threshold) (Matthew Justin Streb, 2013).Ambang 


\section{Jurnal Ilmiah Mahasiswa FAKULTAS HUKUM UNIMAL}

E-ISSN:

ISSN :

Volume 1 Nomor 1 Januari-April 2020 (halaman 38-58)

batas pemilihan umum (electoral threshold) umumnya dibagi ke dalam dua klasifikasi, yaitu ambang batas efektif (effective theshold) dan ambang batas formal (formal threshold).

Andrew Reynolds menjelaskan bahwa ambang batas efektif merupakan pengaturan yang lahir dari perhitungan matematis di dalam sistem Pemilihan Umum (mathematical by product of features of electoral systems). Ambang batas efektif diterjemahkan pula sebagai ambang batas terselubung (hidden threshold) atau ambang batas alami (natural threshold) dikarenakan Undang-Undang tidak mencantumkan secara tegas persentase suara minimal yang harus dipenuhi. Ambang batas efektif menempatkan besaran daerah pemilihan (district magnitude) sebagai aspek matematis yang penting dalam penentuan perolehan kursi (Andrews Reynlods, dkk, 2013).

Bedanya dengan ambang batas formal, ambang batas efektif memang tidak dituliskan dalam aturan hukum tentang persentasenya secara tegas, namun hanya bersifat alamiah atau muncul secara alamiah. Sementara ambang batas formal, besaran persentasenya dicantumkan dengan jelas dan tegas di dalam aturan hukumnya. Ambang batas tersebut dipaksakan untuk dilaksanakan dalam pemilu berdasarkan aturan Perundang-Undangan yang berlaku, sehingga partai yang tidak mendapatkan suara mencapai ambang batas, tidak berhak mendapatkan kursi atau tidak berhak diikutkan dalam penghitungan kursi. Dalam sistem pemilihan Presiden dan Wakil Presiden (Pemilu 2019), berarti partai politik atau koalisi partai politik yang tidak mencapai ambang batas, tidak berhak mengajukan calon Presiden dan Wakil Presiden.

Perkembangan pemilihan umum dalam konsep demokrasi Indonesia, membawa threshold pada setiap sistem bentuk pemilihan umum, mulai dari electoral threshold seabagai syarat partai politik dapat ikut serta dalam Pemilu, parliementary threshold sebagai bentuk ambang batas partai untuk dapat menduduki kursi parlemen pusat, hingga presidential threshold sebagai ambang batas suara partai untuk mengusung calon Presiden dan Wakil Presiden dalam Pemilihan Umum.

Dalam Pemilu di Indonesia, kata threshold dijumpai dalam tiga kasus pengaturan sistem Pemilu. Ambang batas (threshold) yang pertama kali diterapkan di Indonesia adalah saat menjelang Pemilu 2004, yakni electoral treshold yang ditetapkan pada tahun 1999. Ambang batas ini dimaknai sebagai syarat perolehan suara maupun kursi bagi partai untuk bisa ikut kembali di Pemilu mendatang. Hal ini tertuang dalam UU Nomor 3 Tahun 1999 Tentang Pemilihan Umum. Pasal 39 UU No. 3 Tahun 1999 menyatakan : "Untuk dapat mengikuti Pemilihan Umum berikutnya, Partai Politik harus memiliki sebanyak 2\% (dua per seratus) dari jumlah kursi DPR atau memiliki sekurang-kurangnya 3\% (tiga per seratus) jumlah kursi DPRD I atau DPRD II yang tersebar sekurang-kurangnya di $1 / 2$ (setengah) jumlah propinsi dan di $1 / 2$ (setengah) jumlah kabupaten/kotamadya seluruh Indonesia berdasarkan hasil Pemilihan Umum”. Ketentuan ini dicantumkan kembali pada Pasal 143 ayat (1) UU Nomor 12 Tahun 2003. Inilah yang disebut electoral threshold, yaitu batas minimal perolehan kursi partai agar dapat mengikuti Pemilu berikutnya.

Dalam Pasal 5 ayat (4) UU Nomor 23 Tahun 2003 tentang Pemilihan Umum Presiden dan Wakil Presiden disebutkan bahwa: "Pasangan Calon sebagaimana dimaksud pada ayat (1) hanya dapat diusulkan oleh partai politik atau gabungan partai politik yang memperoleh sekurang-kurangnya 15\% (lima belas persen) dari jumlah kursi DPR atau 20\% (dua puluh persen) dari perolehan suara sah secara nasional dalam Pemilu anggota DPR". Dengan demikian, Pasal 5 UU Nomor 23 Tahun 2013 ini mengatur tentang pasangan calon Presiden dan Wakil Presiden diajukan oleh partai atau gabungan partai yang memiliki sedikitnya 15 persen kursi DPR atau 20 persen suara Pemilu DPR. Ketentuan ini dinaikkan menjadi 20 persen kursi DPR atau 25 persen suara Pemilu DPR oleh Pasal 9 UU Nomor 42 Tahun 2008 yang mengatakan: "Pasangan Calon diusulkan oleh Partai Politik atau Gabungan Partai Politik peserta Pemilu yang 


\section{Jurnal Ilmiah Mahasiswa FAKULTAS HUKUM UNIMAL}

E-ISSN:

ISSN :

Volume 1 Nomor 1 Januari-April 2020 (halaman 38-58) memenuhi persyaratan perolehan kursi paling sedikit $20 \%$ dari jumlah kursi DPR atau memperoleh $25 \%$ dari suara sah nasional dalam Pemilu anggota DPR, sebelum pelaksanaan Pemilu Presiden dan Wakil Presiden." Aturan tentang Pemilu ini kemudian diatur kembali dalam UU Nomor 7 Tahun 2017 tentang Pemilihan umum. Inilah yang disebut presidential threshold, yaitu batas minimal perolehan kursi atau suara partai atau koalisi partai agar bisa mengajukan pasangan calon Presiden dan Wakil Presiden.

Pasal 202 ayat (1) UU Nomor 10 Tahun 2008 menyatakan bahwa "partai politik peserta Pemilu harus memenuhi ambang batas perolehan suara minimal 2,5 persen suara dari jumlah suara sah secara nasional dan hanya diterapkan dalam penentuan perolehan kursi DPR dan tidak berlaku untuk DPRD Provinsi atau DPRD Kabupaten/Kota nasional." Saat Pemilihan Umum 2014, dalam Undang- Undang Nomor 8 Tahun 2012, ambang batas parlemen yang awalnya 2,5 persen ditetapkan menjadi sebesar 3,5 persen dan berlaku nasional untuk semua anggota DPR dan DPRD. Namun UU tersebut digugat oleh 14 partai politik ke Mahkamah Konstitusi (MK). Pada akhirnya MK menetapkan ambang batas 3,5\% tersebut hanya berlaku untuk DPR dan ditiadakan untuk DPRD. Inilah yang dimaksud parliamentary treshold, yakni ambang batas perolehan suara minimal partai politik dalam Pemilihan Umum untuk diikutkan dalam penentuan perolehan kursi di Dewan Perwakilan Rakyat.

Threshold pertama kali diformalkan (ditegaskan presentasenya) dalam aturan yang berlaku adalah pada tahun 1999, yang kemudian menjadi salah satu dasar hukum pelaksanaan Pemilu tahun 2004. Dengan penjelasan di atas, dapat dipahami bahwa threshold (ambang batas) antara electoral, parliamentary dan presidential memiliki pengertian yang berbeda-beda. Electoral dan presidential adalah syarat bagi partai peserta Pemilu untuk dapat mengikuti Pemilu, sedangkan parliamentary adalah syarat untuk mendapatkan kursi di parlemen.

Salah satu konten yang menjadi agenda perubahan dalam UUD 1945 adalah mengenai sistem pengisian jabatan Presiden dan Wakil Presiden di Indonesia. Hal ini dirumuskan dalam perubahan ketiga UUD 1945 yang diputuskan pada Rapat Paripurna MPR-RI ke-7, tanggal 9 November 2001 Sidang Tahunan MPR-RI. Mekanisme pemilihan Presiden dan Wakil Presiden diatur secara lebih rinci sebelumnya dalam Pasal 6A UUD 1945 yang dijabarkan ke dalam lima ayat berikut:

(1) Presiden dan Wakil Presiden dipilih dalam satu pasangan secara langsung oleh rakyat.

(2) Pasangan calon Presiden dan Wakil Presiden diusulkan oleh partai politik atau gabungan partai politik peserta pemilihan umum sebelum pelaksanaan pemilihan umum.

(3) Pasangan calon Presiden dan Wakil Presiden yang mendapatkan suara lebih dari lima puluh persen dari jumlah suara dalam pemilihan umum dengan sedikitnya dua puluh persen suara di setiap provinsi yang tersebar di lebih dari setengah jumlah provinsi di Indonesia, dilantik menjadi Presiden dan Wakil Presiden.

(4) Dalam hal tidak ada pasangan calon Presiden dan Wakil Presiden terpilih, dua pasangan calon yang memperoleh suara terbanyak pertama dan kedua dalam pemilihan umum dipilih oleh rakyat secara langsung dan pasangan yang memperoleh suara rakyat terbanyak dilantik sebagai Presiden dan Wakil Presiden.

(5) Tata cara pelaksanaan pemilihan Presiden dan Wakil Presiden lebih lanjut diatur dalam undang-undang (UUD 1945).

Disahkannya Pasal 6A ayat (1) UUD 1945 ini secara otomatis mencabut kewenangan MPR-RI untuk memilih Presiden dan Wakil Presiden dan beralih pada ketentuan baru bahwa yang berwenang untuk memilih Presiden dan Wakil Presiden adalah hak rakyat Indonesia, oleh karena itu keterlibatan rakyat dan penguatan kedaulatan rakyat semakin diakui karena rakyat bisa secara langsung memilih pemimpin negaranya sendiri. Keterlibatan partai politik untuk mengajukan calon Presiden dan Wakil Presiden seperti yang diatur dalam Pasal 6A ayat (2) juga 


\section{Jurnal Ilmiah Mahasiswa FAKULTAS HUKUM UNIMAL}

E-ISSN:

ISSN :

Volume 1 Nomor 1 Januari-April 2020 (halaman 38-58) menjadi implikasi positif terhadap kedaulatan partai politik yang secara konstitusional diakui dalam sistem pemilihan kepala negara di Indonesia. Secara normatif, perkembangan sistem demokrasi di Indonesia sangat dipengaruhi oleh perubahan UUD NRI 1945 yang berkaitan dengan sistem pengisian jabatan Presiden dan Wakil Presiden ini, dimana rakyat diberikan peran yang besar dalam menentukan kebijakan-kebijakan nasional.

Sebagaimana dijelaskan diatas bahwa konstitusi negara telah beberapa kali diubah berdasarkan semangat reformasi bangsa Indonesia. Periode pertama perubahan UUD NRI Tahun 1945 dimulai pada tahun 1999 dan periode kedua pada tahun 2000, namun pada kedua periode tersebut belum diubah ketentuan mengenai pengisian jabatan kepala negara. Lalu pada perubahan ketiga terdapat beberapa ketentuan terkait dengan syarat untuk menjadi Presiden dan Wakil Presiden dan mekanisme pemilihan langsung oleh rakyat. Ketentuan yang dimaksud dinyatakan dalam Pasal 6A UUD NRI Tahun 1945. Perlu diketahui bahwa perdebatan awal dalam melakukan perubahan UUD NRI Tahun 1945 tidak lepas dari pembahasan mengenai sistem pemilihan yang dianut langsung atau tidak langsung, selain itu perdebatan yang muncul adalah terkait dengan syarat personal seseorang untuk menjadi Presiden dan Wakil Presiden (Titik Triwulan Tutik, 2017).

Pemilihan langsung Presiden dan Wakil Presiden oleh rakyat merupakan salah satu amanat dari demokrasi partisipatoris yang akan memberikan peluang yang luas kepada rakyat untuk berpartisipasi secara efektif dalam proses pengambilan keputusan yang menyangkut kebijakan publik. Prinsip dalam demokrasi partisipatoris adalah persamaan bagi seluruh warga negara dewasa untuk ikut menentukan agenda dan melakukan kontrol terhadap pelaksanaan agenda yang telah diputuskan secara bersama. Hal ini dilakukan agar perjalanan kehidupan bernegara mendapatkan pemahaman yang jernih pada sasaran yang tepat dalam rangka terwujudnya pemerintahan yang baik (Robert Dahl, 2001).

Demokrasi partisipatoris pada hakekatnya adalah demokrasi yang secara sadar akan memberdayakan rakyat dalam rangka mewujudkan pemerintahan 'dari rakyat, oleh rakyat dan untuk rakyat dan bersama rakyat'. Adanya pemberdayaan rakyat yang akan berupa partisipasi langsung ini penting, karena sistem perwakilan rakyat melalui lembaga perwakilan tidak pernah dapat diandalkan sebagai satusatunya saluran aspirasi rakyat. Karena itulah, prinsip "representation in ideas' dibedakan dari 'representation in presence", karena perwakilan fisik saja belum tentu mencerminkan keterwakilan gagasan atau aspirasi (Robert Dahl, 2001).

Pasal 6A UUD NRI 1945 tidak menyebutkan mengenai ketentuan ambang batas pencalonan Presiden dan Wakil Presiden/presidential threshold, namun berdasarkan ketentuan Pasal 6A ayat (5) UUD NRI Tahun 1945 yang menyatakan bahwa; "Tata cara pelaksanaan pemilihan Presiden dan Wakil Presiden diatur lebih lanjut dalam Undang-undang.” Konstitusi Negara kita memberikan kewenangan konstitusional kepada Pemerintah bersama-sama Dewan Perwakilan Rakyat untuk membuat aturan yang lebih komprehensif mengenai tata cara pelaksanaan pemilihan presiden dan wakil presiden karena dalam UUD NRI 1945 tidak memuat secara rinci dan konkrit terkait materi muatan tersebut. Maka kemudian dibentuklah undangundang tentang pemilihan Presiden dan Wakil Presiden yang memuat ketentuan presidential threshold. Ini merupakan kesepakatan politik antara beberapa fraksi di Dewan Perwakilan Rakyat dengan sebuah pertimbangan bahwa demi terciptanya sistem presidensil yang kuat dan efektif maka persyaratan pengajuan Presiden dan Wakil Presiden berdasarkan jumlah suara sah nasional ini menjadi diperlukan oleh partai politik atau gabungan partai politik sebagai bukti legitimasi dari rakyat (Putusan Mahkamah Konstitusi, 2008).

Adapun kesepakatan mendasar dalam melakukan perubahan terhadap UUD NRI Tahun 1945 ini antara lain; Pertama, tidak mengubah bagian pembukaan UUD NRI Tahun 1945, kedua, tetap mempertahankan Negara Kesatuan Republik Indonesia, ketiga, perubahan dilakukan 


\section{Jurnal Ilmiah Mahasiswa FAKULTAS HUKUM UNIMAL}

E-ISSN:

ISSN :

Volume 1 Nomor 1 Januari-April 2020 (halaman 38-58)

dengan cara adendum, keempat, mempertegas sistem pemerintahan presidensial dan, kelima, penjelasan UUD NRI Tahun 1945 ditiadakan sehingga hal-hal normatif dalam bagian penjelasan diangkat kedalam pasal-pasal (Ria Casmi, Arrsa, 2014).

\section{Pengaturan Presidential Threshold dalam Pemilu 2019 di Indonesia}

Sebagaimana dijelaskan sebelumnya bahwa konstitusi negara telah beberapa kali diubah berdasarkan semangat reformasi bangsa Indonesia. Periode pertama perubahan UUD NRI Tahun 1945 dimulai pada tahun 1999 dan periode kedua pada tahun 2000, namun pada kedua periode tersebut belum diubah ketentuan mengenai pengisian jabatan kepala negara. Lalu pada perubahan ketiga tahun 2001 terdapat beberapa ketentuan terkait dengan syarat untuk menjadi Presiden dan Wakil Presiden dan mekanisme pemilihan langsung oleh rakyat. Ketentuan yang dimaksud dinyatakan dalam Pasal 6A UUD NRI Tahun 1945. Perlu diketahui bahwa perdebatan awal dalam melakukan perubahan UUD NRI Tahun 1945 tidak lepas dari pembahasan mengenai sistem pemilihan yang dianut langsung atau tidak langsung, selain itu perdebatan yang muncul adalah terkait dengan syarat personal seseorang untuk menjadi Presiden dan Wakil Presiden (Titik Triwulan Tutik, 2017).

Pemilihan langsung Presiden dan Wakil Presiden oleh rakyat merupakan salah satu amanat dari demokrasi partisipatoris yang akan memberikan peluang yang luas kepada rakyat untuk berpartisipasi secara efektif dalam proses pengambilan keputusan yang menyangkut kebijakan publik. Prinsip dalam demokrasi partisipatoris adalah persamaan bagi seluruh warga negara dewasa untuk ikut menentukan agenda dan melakukan kontrol terhadap pelaksanaan agenda yang telah diputuskan secara bersama. Hal ini dilakukan agar perjalanan kehidupan bernegara mendapatkan pemahaman yang jernih pada sasaran yang tepat dalam rangka terwujudnya pemerintahan yang baik (Robert Dahl, 2001).

UU Nomor 23 tahun 2003 tentang Pemilihan Umum Presiden dan Wakil Presiden adalah instrumen hukum pertama yang dibuat untuk mengatur tentang mekanisme pilpres sesuai yang diamanatkan oleh Pasal 6A ayat (1) sampai ayat UUD NRI 1945 setelah perubahan. Pasal 5 ayat (4) undang-undang a quo merumuskan sebuah regulasi baru bahwa partai politik yang dapat mencalonkan pasangan Presiden dan Wakil Presiden hanyalah partai politik atau gabungan partai politik yang telah memenuhi syarat (electoral treshold) sekurang-kurangnya 15\% dari jumlah kursi Dewan Perwakilan Rakyat (DPR) dan 20\% dari perolehan suara sah secara nasional dalam Pemilu Anggota DPR (Harun Al-Rasid, 1999).

Berdasarkan ketentuan undang-undang inilah kemudian dilaksanakan pilpres pertama kali yang dipilih secara langsung oleh rakyat serta menggunakan sistem presidential threshold dalam pengajuan calonnya. Pilpres yang dilaksanakan pada tanggal 5 Juli 2004 tersebut diikuti oleh 5 (lima) pasang calon Presiden dan Wakil Presiden:

1) Wiranto-Salahuddin Wahid dicalonkan oleh gabungan partai politik yang terdiri dari partai Golkar dan Parta Kebangkitan Bangsa yang memiliki akumulasi 32,72\% kursi di DPR serta memperoleh 32,15\% suara sah secara nasional dalam Pemilu Anggota DPR;

2) Megawati Soekarnoputri-Hasyim Muzadi yang dicalonkan oleh gabungan partai politik yang terdiri dari Partai Demokrasi Indonesia Perjuangan dan PDS yang memiliki akumulasi $22,18 \%$ kursi di DPR serta memperoleh 20,66\% suara sah secara nasional dalam Pemilu Anggota DPR;

3) Amien Rais Siswono Yudo Husodo dicalonkan oleh gabungan partai politik yang terdiri dari oleh Partai Amanat Nasional, PBR, PKS, PNBK, dan PSI yang memiliki 12,19\% kursi di DPR serta memperoleh 13,78\% suara sah secara nasional dalam Pemilu Anggota DPR; 


\section{Jurnal Ilmiah Mahasiswa FAKULTAS HUKUM UNIMAL}

E-ISSN:

ISSN :

Volume 1 Nomor 1 Januari-April 2020 (halaman 38-58)

4) Susilo Bambang Yudhoyono-Jusuf Kalla dicalonkan oleh gabungan partai politik yang terdiri dari Partai Demokrat, Partai Bulan Bintang, dan Partai Keadilan dan Persatuan Indonesia yang memiliki akumulasi $12,18 \%$ kursi di DPR serta memperoleh $11,33 \%$ suara sah secara nasional dalam Pemilu Anggota DPR;

5) Hamzah Haz-Agum Gumelar dicalonkan oleh Partai Persatuan Pembangunan yang memiliki $10,55 \%$ kursi di DPR serta memperoleh $8,15 \%$ suara sah secara nasional dalam Pemilu Anggota DPR yang dilaksanakan pada tanggal 4 April 2004 sebelumnya. Hasil pemilihan umum ini dimenangkan oleh pasangan Susilo Bambang Yudhoyono- Jusuf Kalla dengan persentase perolehan suara sebanyak 60,62\% dari jumlah 150.644.184 orang pemilih terdaftar pada pemilihan umum presiden dan wakil presiden putaran kedua yang dilaksanakan pada tanggal 20 September 2004.

Dalam Pasal 5 ayat (4) UU Nomor 23 Tahun 2003 tentang Pemilihan Umum Presiden dan Wakil Presiden disebutkan bahwa: "Pasangan Calon sebagaimana dimaksud pada ayat (1) hanya dapat diusulkan oleh partai politik atau gabungan partai politik yang memperoleh sekurang-kurangnya 15\% (lima belas persen) dari jumlah kursi DPR atau 20\% (dua puluh persen) dari perolehan suara sah secara nasional dalam Pemilu anggota DPR". Dengan demikian, Pasal 5 UU Nomor 23 Tahun 2003 ini mengatur tentang pasangan calon Presiden dan Wakil Presiden diajukan oleh partai atau gabungan partai yang memiliki sedikitnya $15 \%$ kursi DPR atau 20\% suara Pemilu DPR. Ketentuan ini dinaikkan menjadi 20\% kursi DPR atau 25\% suara Pemilu DPR oleh Pasal 9 UU Nomor 42 Tahun 2008.

Undang-undang Nomor 42 Tahun 2008 Tentang Pemilihan Umum Presiden dan Wakil Presiden adalah instrumen hukum kedua yang dibuat untuk menyempurnakan aturan tentang mekanisme pilpres sebagaimana yang diamanatkan oleh Pasal 6A ayat (1) sampai ayat (5) UUD NRI 1945. Ketentuan presidential threshold dalam undang-undang ini dirubah menjadi lebih tinggi persentasenya dari muatan yang dirumuskan dalam undang-undang sebelumnya. Ketentuan sebagaimana dimaksud tertera dalam Pasal 9 undang-undang a quo yang berbunyi; "Pasangan Calon diusulkan oleh Partai Politik atau Gabungan Partai Politik peserta pemilu yang memenuhi persyaratan perolehan kursi paling sedikit 20\% (dua puluh persen) dari jumlah kursi DPR atau memperoleh $25 \%$ (dua puluh lima persen) dari suara sah nasional dalam pemilu anggota DPR, sebelum pelaksanaan Pemilu Presiden dan Wakil Presiden (Undang-undang Nomor 42 Tahun 2008).

Undang-undang ini dijadikan landasan pelaksanaan Pemilu Presiden dan Wakil Presiden tahun 2009 sekaligus tahun 2014. Pemilu yang dilaksanakan pada tanggal 8 Juli 2009 tersebut diikuti oleh 3 (tiga) pasang calon Presiden dan Wakil Presiden, yaitu:

1) Megawati soekarnoputri-prabowo subianto yang dicalonkan oleh gabungan partai politik yang terdiri dari PDI-P dan partai Gerindra yang memiliki akumulasi 21,6\% kursi di DPR serta memperoleh $18,49 \%$ suara sah secara nasional dalam pemilu anggota DPR;

2) Susilo bamabang yudhoyono-budiono yang dicalonkan oleh gabungan partai politik yang terdiri dari partai Demokrat, PPP, PKB, PKS, dan PAN yang memiliki akumulasi 56,08\% kursi di DPR serta memperoleh 45,00\% suara sah secara nasional dalam pemilu anggota DPR;

3) Jusuf kalla-wiranto yang dicalonkan oleh gabungan partai politik yang terdiri dari partai Golkar dan partai Hanura yang memiliki akumulasi 22,32\% kursi di DPR serta memperoleh 18,22\% suara sah secara nasional dalam pemilu anggota DPR.

Sedangkan pada Pemilu Presiden dan Wakil Presiden yang dilaksanakan pada tanggal 9 Juli 2014 tersebut diikuti oleh 2 (dua) pasang calon Presiden dan Wakil Presiden, yaitu: 
Jurnal Ilmiah Mahasiswa

FAKULTAS HUKUM UNIMAL
E-ISSN:

ISSN :

Volume 1 Nomor 1 Januari-April 2020 (halaman 38-58)

1) Prabowo Subianto-Hatta Rajasa yang dicalonkan olehgabungan partai politik yang terdiri dari Partai Gerindra, PPP, PKS, PAN, dan Partai Golkar yang memiliki akumulasi 47,47\% kursi di DPR;

2) Joko Widodo-Jusuf Kalla yang dicalonkan oleh gabungan partai politik yang terdiri dari PDI-P, PKB, Nasdem dan Partai Hanura yang memiliki akumulasi 39,96\% kursi di DPR dalam Pemilu Anggota DPR.

Aturan tentang Pemilu kemudian diatur kembali dalam UU Nomor 7 Tahun 2017 tentang Pemilihan Umum. Inilah yang disebut presidential threshold, yaitu batas minimal perolehan kursi atau suara partai atau koalisi partai agar bias mengajukan pasangan calon Presiden dan Wakil Presiden. Perihal presidential threshold itu sendiri merupakan suatu konsep yang bertujuan untuk mengusulkan calon Presiden dan Wakil Presiden yang berkualitas.

Undang-Undang Nomor 7 Tahun 2017 Tentang Pemilihan Umum adalah regulasi terbaru terkait kepemiluan yang disahkan dalam rapat paripurna Dewan Perwakilan Rakyat (DPR) Republik Indonesia pada dini hari tanggal 21 Juli 2017. Intrumen hukum yang sempat menuai polemik terkait presidential threshold (ambang batas bagi partai politik atau gabungan partai politik untuk mengajukan calon Presiden atau Wakil Presiden) ini memuat 573 pasal, penjelasan, 4 lampiran, dan terfregmen dalam beberapa buku; Buku kesatu tentang Ketentuan Umum, Buku kedua tentang Penyelenggara Pemilu, Buku ketiga tentang Pelaksanaan Pemilu, Buku keempat tentang Pelanggaran Pemilu, Sengketa Proses Pemilu, dan Perselisihan Hasil Pemilu, serta Buku Kelima tantang Tindak Pidana Pemilu, dan Buku keenam Penutup. Undang-Undang ini diundangkan oleh Menteri Hukum dan hak Asasi Manusia, Yosanna H. Laoly pada tanggal 16 Agustus 2017.

Undang-Undang Nomor 7 Tahun 2017 tentang Pemilihan Umum yang menjadi acuan Pemilu 2019, merupakan penyederhanaan dan penggabungan dari 3 (tiga) buah Undang-Undang sebelumnya, yakni UU Nomor 42 Tahun 2008 tentang Pilpres, UU Nomor 15 Tahun 2011 tentang Penyelenggara Pemilu, dan UU Nomor 8 Tahun 2012 tentang Pemilu Anggota DPR, DPD, dan DPRD. Alasan penyederhanaan dan penggabungan ini dimaksudkan untuk mewujudkan Pemilu yang adil dan berintegritas, menjamin konsistensi pengaturan sistem Pemilu, mencegah duplikasi pengaturan dan ketidakpastian hukum pengaturan Pemilu, dan menemukan masalah masalah pengaturan penyelenggara dan peserta Pemilu, sistem pemilihan, manajemen Pemilu, dan penegakan hukum dalam satu undang-undang Pemilu. Setidaknya dalam UU Nomor 7 Tahun 2017 ini terdapat 5 poin penting, sebagaimana yang telah dibahas di bab sebelumnya (Kementerian Dalam Negeri, 2016). Salah satunya adalah pengaturan ketentuan presidential threshold. Presidential threshold adalah ambang batas bagi partai politik atau gabungan partai politik untuk mengajukan calon Presiden atau Wakil Presiden. Dalam Pasal 222 UU Nomor 7 Tahun 2017, menyatakan: "Pasangan Calon diusulkan oleh Partai Politik atau Gabungan Partai Politik peserta pemilu yang memenuhi persyaratan perolehan kursi paling sedikit 20\% (dua puluh persen) dari jumlah kursi DPR atau memperoleh 25\% (dua puluh lima persen) dari suara sah secara nasional pada pemilu anggota DPR sebelumnya."Ambang batas itulah yang akan dijadikan syarat untuk mengajukan calon Presiden pada pemilu masal 2019. Syarat Pilpres 2019 menggunakan ambang batas pemilu tahun 2014(UU Nomor 42 Tahun 2008).

Dengan ketentuan Pasal 222 tersebut, dapat dipahami bahwa hanya partai yang memiliki perolehan suara minimal 20\% dari jumlah kursi DPR atau memperoleh $25 \%$ suara sah secara nasional. Namun jika tidak memiliki suara sampai pada ambang batas tersebut, maka mau tidak mau partai-partai politik harus berkoalisi untuk memenuhi ambang batas agar dapat mencalonkan Presiden dan Wakilnya, sehingga terpenuhi syarat minimal 20\% kursi di DPR atau 25\% suara sah secara nasional. Hal ini dibenarkan berdasarkan Pasal 222 ini, dan juga Pasal 223 


\section{Jurnal Ilmiah Mahasiswa FAKULTAS HUKUM UNIMAL}

E-ISSN:

ISSN :

Volume 1 Nomor 1 Januari-April 2020 (halaman 38-58)

poin (2) UU Nomor 7 Tahun 2017 tentang Pemilihan Umum, yang mengatakan: "Partai Politik dapat melakukan kesepakatan dengan Partai Politik lain untuk melakukan penggabungan dalam mengusulkan Pasangan Calon."

Putusan Mahkamah Konstitusi Nomor 14/PUU-XI/2013 menyatakan bahwa Pemilu Presiden dan Wakil Presiden harus dilaksanakan secara serentak dengan Pemilu Legislatif pada Tahun 2019, dijelaskan bahwa Pemilu legislatif yang selanjutnya disebut Pileg, sehingga dengan ketetapan itu, maka acuan perolehan kursi atau suara partai-partai adalah merujuk kepada hasil Pemilu 2014. Sedangkan dalam hasil Pileg 2014, tidak ada satupun partai yang memenuhi minimal ambang batas 20\% kursi DPR atau 25\% suara sah nasional. Berikut daftar hasil Pileg 2014 (https://editorialindonesia.com/2017):

a. Partai Demokrasi Indonesia Perjuangan (PDIP) 109 kursi/ 23.681.471(18,95\%) suara.

b. Partai Golongan Karya (Golkar) 91 kursi / $18.432 .312(14,75 \%)$ suara.

c. Partai Gerakan Indonesia Raya (Gerindra) 73 kursi / 14.760.371 (11,81\%) suara.

d. Partai Demokrat 61 kursi / 12.728 .913 (10,19\%) suara.

e. Partai Amanat Nasional (PAN) 49 kursi / 9.481 .621 (7,59\%) suara.

f. Partai Kebangkitan Bangsa (PKB) 47 kursi / 11.298.957 (9,04\%) suara.

Dengan melihat hasil perolehan suara partai-partai yang mengikuti Pileg 2014, maka dapat dipastikan partai-partai itu harus melakukan koalisi, membangun kekuatan dengan partai yang lainnya agar dapat mengusung calon Presiden dan Wakil Presiden.

Dalam naskah akademik rancangan Undang-Undang Pemilihan Umum, dikatakan bahwa alasan diadakannya ambang batas, yang dalam hal ini presidential threshold, bertujuan untuk memperkuat sistem pemerintahan presidensial atau membentuk sistem pemerintahan presidensial yang efektif. Indonesia adalah negara yang menganut sistem pemerintahan Presidensiil. Dengan tetap diberlakukannya aturan ambang batas di Pemilu 2019 diharapkan dapat semakin mengokohkan sistem Presidensiil yang dianut Indonesia.

Menurut Jimly Asshiddiqie, pengaturan ambang batas (threshold) merupakan mekanisme yang niscaya digunakan dalam sistem presidensial dengan multi partai. Presiden membutuhkan dukungan mayoritas diparlemen. Tanpa dukungan mutlak, Presiden sangat mungkin menjadi kurang decisive dalam upaya menggerakkan jalannya pemerintahan dan pembangunan seharihari.Dengan adanya sistem threshold ini, dalam jangka panjang diharapkan dapat menjamin penyederhanaan jumlah partai politik dimasa yang akan datang. Makin tinggi angka ambang batas, diasumsikan makin cepat pula upaya mencapai kesederhanaan jumlah partai politik (Jimly Asshiddiqie,2011).

Perihal ambang batas bagi partai politik atau gabungan partai politik untuk mengajukan calon presiden atau wakil presiden, undang-undang ini menegaskan bahwa calon Presiden dan Wakil Presiden diusulkan dalam 1 (satu) pasangan oleh partai politik atau gabungan partai politik yang memenuhi persyaratan perolehan kursi paling sedikit 20\% (dua puluh persen) dari jumlah kursi DPR RI atau memperoleh 25\% (dua puluh lima persen) dari suara sah secara nasional pada Pemilu anggota DPR sebelumnya. Partai politik atau gabungan partai politik sebagaimana dimaksud hanya dapat mencalonkan 1 (satu) pasangan calon sesuai dengan mekanisme internal partai politik dan/atau musyawarah gabungan partai politik yang dilakukan secara demokratis dan terbuka. Hal ini diatur secara gamblang dalam Pasal 221 - Pasal 223 UU No.7 Tahun 2017 yang berbunyi:

Pasal 221 : Calon Presiden dan Wakil Presiden diusulkan dalam 1 (satu) pasangan oleh Partai Politik atau Gabungan Partai Pottik.

Pasal 222 : Pasangan Calon diusulkan oleh Partai Politik atau Gabungan Partai Politik Peserta Pemilu yang memenuhi persyaratan perolehan kursi paling sedikit $20 \%$ (dua puluh 


\section{Jurnal Ilmiah Mahasiswa FAKULTAS HUKUM UNIMAL}

E-ISSN:

ISSN :

Volume 1 Nomor 1 Januari-April 2020 (halaman 38-58) persen) dari jumlah kursi DPR atau memperoleh 25\% (Dua puluh lima persen) dari suara sah secara nasional pada Pemilu anggota DPR sebelumnya.

Pasal 223 : 1) Penentuan calon Presiden dan/atau calon Wakil Presiden dilakukan secara demokratis dan terbuka sesuai dengan mekanisme internal Partai Politik bersangkutan,

2) Partai Politik dapat melakukan kesepakatan dengan Partai Politik lain untuk melalokan penggabungan dalam mengusulkan Pasangan Calon. 3) Partai Politik atau Gabungan Partai Politik sebagaimana dimaksud pada ayat (2) hanya dapat mencalonkan 1 (satu) Pasangan Calon sesuai dengan mekanisme internal Partai Politik dan/atau musyawarah Gabungan Partai Politik yang dilakukan secara demokratis dan terbuka. 4) Calon Presiden dan/atau calon Wakil Presiden yang telah diusulkan dalam satu pasangan oleh Partai Politik atau Gabungan Partai Politik sebagaimana dimaksud pada ayat (3) tidak boleh dicalonkan lagi oleh Partai Politik atau Gabungan Partai Politik lainnya (Undang-Undang Nomor 7 Tahun 2017).

Adapun salah satu norma yang saat ini berlaku di UU No. 7 Tahun 2017 tentang Pemilihan Umum ini adalah mengenai ambang batas presiden sebesar 20\% kursi atau 25\% suara sah. Norma ini pula yang saat ini sedang ramai diuji oleh sejumlah pihak ke Mahkamah Konstitusi karena dianggap merupakan pelangaran konstitusi. Lebih kurang pada saat ini (sampai tercatat pada tanggal 11 bulan 9 tahun 2017) telah terkumpul kurang lenbih 9 (sembilan) gugatan mengenai UU No. 7 Tahun 2017 tentang Pemilihan Umum.

Selama masa Reformasi, Indonesia telah melaksanakan Pemilu Presiden dan Wakil Presiden sebanyak empat kali, yakni Pemilu 1999, Pemilu 2004, Pemilu 2009 dan Pemilu 2014, dan ditambah Pemilu 2019 nanti, berarti lima kali Indonesia melaksanakan perhelatan akbar pesta demokrasi Pemilihan Umum. Namun dari empat kali Pemilu yang telah dilaksanakan Indonesia setelah masa Orde Baru, masing-masing Pemilu memiliki ciri khasnya sendiri. Dalam artian keempat Pemilu itu dalam pelaksanaannya tidak seragam bentuk dan sistemnya.

Sistem Pemilu 1999 sama dengan Pemilu 1997 yaitu sistem perwakilan berimbang (proporsional) dengan stelsel daftar. Pemilu 2004 merupakan Pemilu pertama yang memungkinkan rakyat memilih langsung wakil mereka untuk duduk di DPR, DPD, dan DPRD serta memilih langsung Presiden dan Wakil Presiden. Pemilu 2009 merupakan Pemilu ketiga pada masa reformasi yang diselenggarakan secara serenta kuntuk memilih Anggota DPR, AnggotaDPD, serta Anggota DPRD (DPRD Provinsi maupun DPRD Kabupaten/Kota) seIndonesia periode 2009- 2014. Sedangkan untuk memilih Presiden dan Wakil Presiden untuk masa bakti 2009-2014 diselenggarakan setelah beberapa bulan dilakukan Pileg. Pemilu 2009 untuk memilih Anggota DPR, DPRD Provinsi, DPRD Kabupaten/Kota dilaksanakan dengan sistem perwakilan berimbang (proporsional) dengan sistem daftarcalon terbuka. Sedangkan Pemilu tahun 2014 merupakan Pemilu yang keempat pada masa reformasi. Pemilu tahun 2014 juga ditandai dengan beberapa perbaikan dalam hal landasan hukumnya. Pada satu sisi, hal tersebut dapat dimaklumi dalam artian sebagai perbaikan dari legalitas penyelenggaraan Pemilu sebelumnya. Namun di sisi lain, kondisi tersebut menandakan bahwa Pemilu di Indonesia masih mencari bentuknya dengan berbagai macam metamorfosis dalam hal institusionalisasinya.

Dibandingkan dengan Pemilu 2019, ada yang hal menarik antara kedua Pemilu ini, diantaranya dapat dilihat dalam poin penting pelaksanaannya, masalah penting penyelenggaraan Pemilihan Umum Tahun 2014 dan 2019 yang akan disoroti adalah terkait sistem pelaksanaan Pemilunya, yakni serentak dan tidak serentak serta adanya konsep ambang batas. Dalam pemilu 2019, sistem penyelenggaraan Pemilu diatur dengan menyerentakkan Pemilu Presiden dan Pemilu Legislatif. Dua institusi yang terpisah ini diselenggarakan Pemilunya dalam waktu bersamaan (Undang undang 42, 2008). Menariknya, Pemilu 2019 masih tetap menggunakan aturan ambang batas sebagaimana yang diatur dalam UU Nomor 42 Tahun 2008, yang kemudian diatur ulang dalam UU Nomor 7 Tahun 2017. 
Jurnal Ilmiah Mahasiswa FAKULTAS HUKUM UNIMAL
E-ISSN:

ISSN :

Volume 1 Nomor 1 Januari-April 2020 (halaman 38-58)

Dengan demikian, hasil perolehan kursi DPR atau suara sah nasional Pileg di tahun 2014 yang akan digunakan untuk menentukan lagi partai mana saja yang berhak mengusulkan calon Presiden dan Wakilnya. Maka dapat dipastikan akan muncul kubu-kubu yang tergabung dari koalisi beberapa partai akan bersaing dalam Pilpres, sebagaimana yang terjadi di tahun 2014 . Koalisi partai dalam Pemilu Presiden dan Wakil Presiden tahun 2014 mengelompok pada dua koalisi besar. Koalisi Indonesia Hebat $(\mathrm{KIH})$ yang mengajukan pasangan calon Jokowi- Jusuf Kalla dengan koalisi PDIP, PKB, Nasdem, dan Hanura. Sementara itu koalisi lainnya adalah Koalisi Merah Putih (KMP) yang mengajukan pasangan calon Prabowo-Hatta dengan anggota koalisi Gerindra, Golkar, PAN, PKS, dan PPP. Sementara Demokrat memilih tidak berkoalisi dan menjadi partai yang berada di luar saat pemilihan Presiden tahun 2014.

KIH sebagai pemenang Pemilu Presiden tahun 2014, ternyata tidak mendapatkan dukungan dari mayoritas partai di DPR, sebab sebagaimana komposisi kursi ketika itu, KIH mendapat 37\% kursi, atau 207 kursi, sementara KMP 52\% atau 292 kursi. Sementara Demokrat yang $11 \%$ atau 61 kursi adalah partai penyeimbang di luar dua koalisi besar tersebut. Hal ini membuat keadaan di masa awal pasca Pilpres menjadi tidak menentu, ketegangan antara KIH dan KMP sangat terlihat, seperti saat pemilihan pimpinan DPR.Keadaan ini bukan tidak mungkin akan terjadi pula di tahun 2019, walau memang tidak dapat dipungkiri, bahwa perjalanan politik (termasuk sikap dan pilihan politis) sangat dinamis, dapat saja berubah sewaktu-waktu.

Tantangan Pemilu 2019 berdasarkan pengalaman permasalahan Pemilu 2014 adalah bagaimana menghindari atau meminimalisasi tiga masalah dasar dalam praktek Pemilu yaitu pertama oligarki politik dimana sekelompok elit baik dari tingkat nasional sampai pemerintah daerah yang terus menerus dengan segala cara berupaya melanggengkan kekuasaan terutama dengan menggunakan pendekatan kekuasaan yang sudah dimiliki. Kedua adalah oligarki ekonomi- politik yaitu sekelompok orang pemilih modal atau kapital yang sangat besar yang rela membiayai calon-calon peserta Pemilu baik di tingkat nasional maupun lokal dengan harapan mendapatkan konsensi besar pengelolaan sumber daya alam dan proyek di pemerintahan. Masalah ketiga dalam Pemilu adalah meminimalisasi lahir dan berkembangnya para "banditpolitik" yaitu sekelompok orang yang menggunakan pengaruh sosialnya untuk mengelabui Pemilu dengan harapan untuk memenangkan pasangan calon dengan imbalan personal kepada tokoh masyarakat tersebut (Firman Noor dkk,2015).

Dalam pengaturan Pemilu 2019, kursi dan suara yang dipakai untuk menentukan partai yang berhak mengajukan calon Presiden dan Wakil Presiden adalah hasil Pemilu Legislatif di tahun 2014. Hal ini tentu menjadi pertanyaan sekaligus ironi, bagaimana mungkin hasil Pemilu tahun 2014 digunakan untuk Pemilu 2019.

Menurut keterangan Mendagri Tjahjo Kumolo, penggunaan hasil Pemilu Legislatif 2014 untuk digunakan dalam pemilu 2019 dapat dibenarkan dengan lima argumentasi, yaitu (https://kumparan.com/muhamad-iqbal/5-argumentasi-mendagri-pt-hasil-pileg- $\quad$ 2014bisadipakai-pilpres-2019):

a. Putusan MK No. 14/XI-PUU/2013 yang menjadi acuan Pemilu 2019 digelar serentak, diputuskan saat tahapan Pilpres 2014 sedang berlangsung. Sehingga tidak serta merta diberlakukan pada Pilpres Tahun 2014, tapi diberlakukan untuk Pilpres 2019.

b. Pileg dan Pilpres serentak baru pertama kali dilaksanakan tahun 2019, maka pasti rujukan presidential threshold adalah hasil Pileg 2014.Oleh karena itu merupakn hal yang pertama kalinya, maka hasil Pileg bulanApril 2014 itu digunakan sebagai presidential threshold bulan Juli 2014 dan Pilpres 2019. 
Jurnal Ilmiah Mahasiswa

FAKULTAS HUKUM UNIMAL
E-ISSN:

ISSN :

Volume 1 Nomor 1 Januari-April 2020 (halaman 38-58)

c. Soal Pasal 6A UUD 1945 tepatnya ayat (2) bahwa "pasangan calon Presiden dan Wakil Presiden diusulkan oleh partai politik atau gabungan partai politik peserta pemilihan umum sebelum pelaksanaan Pemilihan Umum", menunjukkan semua parpol mestinya bisa mengusung capres cawapres sehingga tak butuh presidential threhold. Namun Tjahjo menjelaskan, ketentuan itu harus dibaca dilengkap ayat (1), ayat (2), ayat (3), ayat (4) dan ayat (5). Pada ayat terakhir itu sangat penting karena berisi: "Tata cara pelaksanaan pemilihan Presiden dan Wakil Presiden lebih lanjut diatur dalam Undang- Undang".

d. Apakah presidential threshold memiliki manfaat positif dalam Pilpres, atau justru sebaliknya lebih banyak mudaratnya? Menurut Tjahjo, Presidential Threshold telah digunakan dua kali Pemilu, hasilnya menunjukkan bukti bahwa presidential threshold sangat positif menjadi alat seleksi awal capres-cawapres terpilih yang wajib mendapat dukungan suara lebih 50 persen dari total suara sah dalam Pemilu.

e. Argumentasi kelima, negara lain yang tidak menggunakan presidential threshold tetap memiliki alat seleksi awal capres- cawapres yang disebut pemilihan pendahuluan, seperti Amerika Serikat. Namun, jika akan menggunakan hasil Pemilu 2014, tentu perlu juga diperhatikan, bahwa dalam rentang waktu 2014 hingga 2019, sangat mungkin terjadi perubahan komposisi dan peta politik partai-partai politik yang ada. Maka agak kurang tepat jika serta merta seolah disamakan kondisi tahun 2014 dengan tahun 2019.

Di samping itu juga, konsep presidential threshold yang akan dilaksanakan pada Pemilu 2019, tidak dapat disamakan dengan presidential threshold pada Pemilu 2014. Walau sama-sama menggunakan konsep ambang batas, namun Pemilu 2014 adalah Pemilu yang terpisah antara legislatif dan eksekutif, sementara Pemilu 2019 adalah Pemilu serentak, sehingga ada perbedaan konseptual dan tentu dalam keadaan yang juga berbeda. Indonesia dalam sistem penyelenggaraan negaranya, mengadopsi prinsip demokrasi konstitusional, harusnya segala kebijakan yang dibuat tidak boleh tanpa ada landasan hukum yang kuat. Disamping itu juga tidak menyalahi prinsip-prinsip demokrasi.

Demikian halnya dengan penggunaan hasil Pileg 2014 untuk Pilpres 2019, harus ada landasan hukum yang mengaturnya yang tidak menyalahi prinsip- prinsip hukum dalam hierarki hukum yang berlaku dan prinsip-prinsip demokrasi. Kalaupun akhirnya pemerintah telah membuat aturan penggunaan hasil Pileg tahun 2014 untuk Pilpres 2019, tetap pemerintah tidak boleh abai dan seperti tak ambil pusing bahwa dari segi konfigurasi politiknya sangat mungkin tidak lagi sama antara pemilu tahun 2014 dengan Pemilu yang akan dilaksanakan tahun 2019.

Sebagaimana yang dilansir kumparan.com, setidaknya ada lima alasan mengapa ketentuan ambang batas (presidential threshold) tidak dapat digunakan di Pemilu 2019, yaitu:

1) Tidak ada basis angka hasil Pemilu Legislatif yang bisa dijadikan dasar untuk prasyarat pencalonan Presiden karena Pemilunya dilaksanakan secara serentak. Alasan koalisi PDIP cs menggunakan angka presidential threshold pada Pileg 2014, dianggap tak logis karena Pemilu 2019 bukan bagian dari Pileg 2014.

2) Ketentuan ambang batas pencalonan Presiden bertentangan dengan Pasal 6A ayat (2) UUD NRI 1945, yang menjamin hak setiap partai politik peserta Pemilu bisa mengajukan pasangan calon Presiden. Secara politik, ketentuan ambang batas pencalonan Presiden juga akan dianggap membatasi kesempatan partai atau warga negara lain maju menjadi pasangan calon Presiden.

3) Ketentuan ambang batas pencalonan Presiden justru berpotensi menyulitkan Jokowi jika mencalonkan diri kembali menjadi Presiden di periode 2019-2024. Apalagi bagi parpol lain yang mengantongi kursi lebih sedikit. 
Jurnal Ilmiah Mahasiswa

FAKULTAS HUKUM UNIMAL
E-ISSN:

ISSN :

Volume 1 Nomor 1 Januari-April 2020 (halaman 38-58)

4) Pembahasan RUU Pemilu ini memperlihatkan kepada publik, bahwa RUU Pemilu yang sedang dibahas hanyalah untuk kepentingan jangka pendek para pembentuk UU, khususnya partai politik peserta Pemilu di DPR dalam menghadapi Pemilu 2019.

5) Alasan penguatan sistem Presidensial dengan besarnya dukungan koalisi kepada satu capres, tak menjamin koalisi itu bertahan. Pada faktanya, di tengah perjalanan pemerintahan, parpol politik bisa bergabung di tengah jalan atau bisa menarik dukungan (https://kumparan.com/muhamad-iqbal/5-alasan-presidential-thresholdtak-bisa- dipakai-dipemilu-2019).

6) Sementara itu, penggunaan istilah threshold sebetulnya kurang tepat untuk diterapkan sebagai aturan keikutsertaan partai politik dalam Pemilu ataupun kemungkinan partai politik untuk mengusung pasangan calon Presiden dan Wakil Presiden.

Pemberlakuan ambang batas minimum bagi keterpilihan Presiden adalah praktek yang sebetulnya tidak lazim dalam negara yang menganut sistem pemerintahan Presidensiil. Maksudnya, kalaupun ada aturan ambang batas (presidential threshold), bukanlah untuk membatasi upaya pencalonan Presiden, tetapi sebagai ketentuan yang mengatur tentang persentase suara minimum sebagai syarat terpilihnya (menangnya) Presiden (Pasal 6A ayat (3) UUD 1945).

Amerika Serikat negara dengan sistem Presidensil yang paling mapan, tidak memiliki aturan ambang batas pencalonan Presiden. Negara-negara di Amerika Latin yang kebanyakan menganut sistem Presidensial multipartai seperti di Indonesia, juga tidak memberlakukan ambang batas pencalonan Presiden dalam Pilpresnya. Umumnya Pilpres dan Pemilu Legislatif di Amerika Latin juga berlangsung serentak (http://www.mahkamahkonstitusi.go.id).

Dari uraian diatas, penulis melihat beberapa dampak dari pemberlakuan presidential threshold yaitu:

1) Partai baru yang telah lulus verifikasi dan dinyatakan sebagai peserta pemilu oleh Komisi Pemilihan Umum tahun 2019 ini tidak mempunyai hak politik dalam pengusungan calon Presiden dan wakil Presiden.

2) Adanya Warga Negara Indonesia yang merasa dicederai hak politiknya sebab yang ia pilih pada pemilu 2014 belum tentu menjadi pilihannya pada pemilu 2019 nanti ataupun dengan kata lain calon yang akan mereka pilih dalam pemilu 2019 tersebut tidak dapat maju/batal maju sebagai calon Presiden dan Wakil Presiden karena adanya aturan presidential threshold tersebut.

\section{KESIMPULAN}

Pengaturan presidential threshold dalam pemilu 2019 di Indonesia awalnya diatur dalam UUD NRI 1945 dinyatakan dalam Pasal 6A, kemudian diatur lebih lanjut dalam UU Nomor 23 Tahun 2003 tentang Pemilihan Umum Presiden dan Wakil Presiden, kemudian diubah dengan UU Nomor 42 Tahun 2008 tentang Pemilihan Umum Presiden dan Wakil Presiden yang selanjutnya diatur kembali dalam UU Nomor 7 Tahun 2017 Tentang Pemilihan Umum yang menyatakan bahwa presidential threshold tetap diberlakukan dalam pemilu serentak tahun 2019 di Indonesia ditetapkan dalam Bab IV bagian kesatu Paragraf 1 Pasal 221 dan 222. Dalam pemberlakuan presidential threshold tidak serta merta hanya menimbulkan dampak positif saja, melainkan ada juga dampak negatifnya seperti adanya partai baru yang telah lulus verifikasi dan dinyatakan sebagai peserta pemilu oleh Komisi Pemilihan Umum (KPU) tahun 2019 ini tidak mempunyai hak politik dalam pengusungan calon Presiden dan wakil Presiden dan adanya Warga Negara Indonesia yang merasa dicederai hak politiknya sebab yang dipilih pada 
Jurnal Ilmiah Mahasiswa

FAKULTAS HUKUM UNIMAL
E-ISSN:

ISSN :

Volume 1 Nomor 1 Januari-April 2020 (halaman 38-58)

pemilu 2014 belum tentu menjadi pilihannya pada pemilu 2019 nanti ataupun dengan kata lain calon yang akan mereka pilih dalam pemilu 2019 tersebut tidak dapat maju/batal maju sebagai calon Presiden dan Wakil Presiden karena adanya aturan presidential threshold tersebut.

\section{SARAN}

Perlu diadakan penelitian lebih lanjut perihal mekanisme pemilihan yang efektif dan berkeadilan dalam Pemilihan Umum (PEMILU) 2019, tanpa mengesampingkan hak-hak partai peserta Pemilu, baik partai lama atau partai baru, yang berkontestasi dalam Pemilihan Presiden dan Wakil Presiden setelah diberlakukan sistem Pemilu serentak. Sepanjang pemilihan umum yang pernah ada di Indonesia, selalu saja ada aturan baru yang mengatur perihal mekanisme pemilu maupun pelaksanaannya. Dengan adanya aturan yang bersifat dinamis dan selalu berubah, membuat sistem peraturan pemilu di Indonesia tidak stabil dan menimbulkan pro kontra bagi sebagian warga negara maupun partai politik. Maka dari itu diharapkan para pembentuk Undang-Undang memikirkan kembali tentang ketentuan peraturan pemilu khususnya mengenai pengaturan presidential threshold terutama dalam hubungannya dengan pemilu serentak, dengan mempertimbangkan kelebihan dan kekurangan dalam penerapan atau pengahapusan prseidential threshold yang bertujuan untuk memperkuat sistem presidensial di Indonesia. 


\section{DAFTAR PUSTAKA}

Ammiruddin, 2003, Pengantar Metode Penelitian Hukum, Raja Grafindo Persada, Jakarta.

A. Mukthie Fadjar, "Pemilu Yang Demokratis dan Berkualitas: Penyelesaian Hukum Pelanggaran Pemilu dan PHPU”, Jurnal Konstitusi, Vol. 6 No. 1 April 2009.

Agus Adhari, "Eksistensi Presidential Trheshold Pada Pemilihan Umum Serentak 2019”, (dalam pdf), hlm. 3

Andrews Reynlods, dkk, 2005, Electoral System Design : The New International IDEA Handbook, International IDEA, Stockholm, dalam Igusti Ngurah Agung Sayoga Raditya, 2013, "Pengaturan Ambang Batas Formal (Formal Threshold) dalam Konteks Sistem Pemilihan Umum yang Demokratis di Indonesia"(Tesis Pascasarjana tidak diterbitkan, Program Pascasarjana Universitas Udayana Denpasar).

Burhan, Ashshofa, 2010, Metode Penelitian Hukum, Rinek Cipta, Jakarta.

Eko handoyo, Pemilu Untuk Pemula Jiid $<$ https://www.researchgate.net/publication/297714664. 10 Maret 2016, 15:40:04 GMT $>/$. Akses tanggal 17 Desember 2018

Fakultas Hukum Universitas Malikussaleh, 2016, Panduan Penulisan Tugas Akhir Skripsi, Unimal Press, Lhokseumawe.

Firman Noor dkk, 2015, Evaluasi Pemilihan Presiden/Wakil Presiden 2014, Institut Riset Kepemiluan, Jakarta.

Harun Alrasid, 1999, Pengisian Jabatan Presiden, Pustaka Utama Grafiti, Jakarta.

Https://id.wikipedia.org/wiki/Pemilihan_umum_Presiden_Indonesia_2014. Tanggal 17 desember 2018, 16:29:03 GMT>/. Akses tanggal 17 desember 2018.

Janpatar Simamora, "Menyongsong Rezim Pemilu Serentak", Jurnal Rechtsvinding, Vol. 3 No. 1, April 2014.

Janedjri M. Gaffar, 2013, Hukum Pemilu Dalam Yurisprudensi Mahkamah Konstitusi, Konstitusi Pres, Jakarta.

Jacob Oetama, 2001, Suara Nurani: Tajuk Rencana Pilihan 1999-2001, Penerbit Buku Kompas, Jakarta.

Jimly Asshiddiqie, 2010, Pengantar Ilmu Hukum Tata Negara, PT Raja Grafindo Utama, Jakarta.

Jimly Asshiddiqie, 2011, Memperkuat Sistem Pemerintahan Presidentil, Universitas Negeri Jember, Jember. 
Joko J. Prihatmoko, 2003, Pemilu 2004 dan Konsolidasi Demokrasi, LP3i, Semarang.

Kementerian Dalam Negeri, 2016, - Naskah Akademik Rancangan UndangUndang tentang Pemilihan Umum, (dalam pdf).

Kementerian Dalam Negeri, 2016, "Naskah Akademik Rancangan UndangUndang tentang Pemilihan Umum", (dalam pdf).

Keterangan Direktur Eksekutif Saiful Mujani Research Center (SMRC), Djayadi Hanan dalam sidang lanjutan terkait uji materiil aturan ambang batas pencalonan presiden (Presidential Threshold/PT) yang tercantum dalam Undang-Undang Nomor 7 Tahun 2017 tentang Pemilihan Umum (UU Pemilu) pada Selasa (14/11), dalam Mahkamah Konstitusi, “Ahli: Ambang Batas Tidak Mungkin Diterapkan dalamPemilu Serentak", 28

November

2017 <http://www.mahkamahkonstitusi.go.id/index.php?page=web.Berita\&id=1 4119\#.WhzJktKWbMy>

Kemendikbud, "ambangbatas", $26 \quad$ November 2017, $<$ https://kbbi.kemdikbud.go.id/entri/AMBANG\%20BATAS Agus Adhari, "Eksistensi Presidential Trheshold Pada Pemilihan Umum Serentak 2019"> (dalam pdf), hlm. 3

Kumparan, "5 Argumentasi Mendagri PT Hasil Pileg 2014 Bisa Dipakai Pilpres 2019”, 28 November 2017, <https://kumparan.com/muhamad-iqbal/5argumentasi-mendagri-pthasil-pileg-2014bisa-dipakai-pilpres-2019> Kumparan, "Alasan Presidential threshold tak Bisa Dipakai di Pemilu 2019”, 28 November 2017, https://kumparan.com/muhamad-iqbal/5-alasanpresidential-threshold-tak-bisa-dipakaidipemilu-2019

Litha Dayanara, Relevansi Sistem Presidential Threshold dalam Model penyelenggaraan Pemilu Serentak, skripsi.

Lutfi Ansori, Jurnal yuridis vol 4 no. 1, Telaah terhadap Presidential Threshold dalam Pemilu Serentak 2019, juni 2017, 15:27

Matthew Justin Streb, 2013, Law and Election Politics: The Rules of the Game, New York, Routledge, dalam Muhammad Siddiq Armia dkk, "Penghapusan Presidential Threshold Sebagai Upaya Pemulihan Hak-hak Konstitusional", Petita, Volume 1 Nomor 2, (Oktober 2016).

M Fadhilah, Presidential Threshold dalam Sistem Presidential, Skripsi.

Muhammad Ghoza Farghan, Enny Nurbaningsih, Presidential Threshold dalam Pemilu Presiden dan Wakil Presiden Pasca Putusan MK No 14/PUU2013, jurnal.

Meriam Budiardjo, 2008, Dasar-dasar Ilmu Politik, PT. Garamedia Pustaka Utama, Jakarta.

Nur Hidayat Sardini, 2011, Restorasi Penyelenggaraan Pemilu di Indonesia, Fajar Media Press, Yogyakarta 
Jurnal Ilmiah Mahasiswa

FAKULTAS HUKUM UNIMAL
E-ISSN:

ISSN :

Volume 1 Nomor 1 Januari-April 2020 (halaman 38-58)

P. Antonius Sitepu, 2011, Studi Ilmu Politik, Graha Ilmu, Yogyakarta.

Peter Ahmad Marzuki, 2009, Penelitian Hukum, Kencana Prenada Media, Jakarta.

Ramlan Subakti, 1992, Memahami Ilmu Politik, PT. Grasindo, Jakarta.

Republik Indonesia, Undang-undang Dasar Negara Republik Indonesia Tahun 1945.

Republik Indonesia, Undang-Undang Republik Indonesia nomor 42 Tahun 2008 Tentang Pemilu Presiden dan Wakil Presiden.

Republik Indonesia, Undang-Undang Nomor 7 Tahun 2017 Tentang Pemilihan Umum.

Republik Indonesia, Putusan Mahkamah Konstitusi No. 14/PUU-XI/2013 dalam perkara pengujian Undang-Undang No. 42 Tahun 2008 tentang Pemilihan Umum Presiden dan Wakil Presiden terhadap UUD NRI Tahun 1945

Republik Indonesia, Keterangan DPR dalam Putusan Mahkamah Konstitusi Nomor 51-5259/PUU-VI/2008 terkait pengujian Undang-undang Nomor 42 Tahun 2008 tentang Pemilihan Umum Presiden dan Wakil Presiden terhadap UUD 1945.

Republik Indonesia, Mahkamah Konstitusi RI, 2010, Naskah Komprehensif Perubahan UndangUndang Dasar RI Tahun 1945 Latar Belakang, Proses dan Hasil Pembahasan 19992002, Sekretariat Jenderal dan Kepaniteraan MK, Jakarta.

Republik Indonesia, putusan MK Nomor 71/PUU-XI/2017 tentang perkara Pengujian UdangUndang Nomor 7 tahun 2017 tentang Pemilihan Umum terhadap UUD NRI Tahun 1945.

Ria Casmi, Arrsa, Pemilu Serentak dan Masa Depan Konsolidasi Demokrasi, Jakarta, Jurnal Konstitusi MK RI Vol 11 No 3, September 2014, 529.

Redaksi Editorial, "Ini Arti Presidential Threshold dan Parliamentary Threshold”, 26 November $2017 \quad<\quad$ https://editorialindonesia.com/2017/07/21/ini-arti-presidentialthresholddanparliamentary>

Redaksi Editorial, "Ini Arti Presidential Threshold dan Parliamentary Threshold”, 26 November 2017, <https://editorialindonesia.com/2017/07/21/ini-artipresidential-threshold-dan parliamentary-threshold>

Robert Dahl, terjemah A Rahman Zainuddin, 2001, Perihal Demokrasi: Menjelajahi Teori dan Praktek Secara Singkat, Yayasan Obor Indonesia, Jakarta.

Sodikin, Vol. 3 No. 1, April 2014, "Pemilu Serentak (Pemilu Legislatif dengan Pemilu Presiden dan Wakil Presiden) dan Penguatan Sistem Presidensiil”, Jurnal Rechtsvinding.

Siswapedia, asas-asas dalam pemilihan umum <https://www.siswapedia.com/asas-asas-dalampemilihan-umum/. Akses Tanggal 16 Desember 2018, 21:20:05 GMT>/. 
Shaun Bowler, Bernard Grofman (ed), Election in Australia, Ireland and Malta underthe Single Trasferable Vote, USA: The University of Michigan Press, 2000, hlm. 31. Lihat juga Didik Suprayitno, Threshold Dalam Wacana Pemilu diakses di www.rumahpemilu.org. <https://id.wikipedia.org/wiki/Pemilihan_umum.tanggal 16 Desember 2018, 21:12:04 GMT $>/$. Akses tanggal 16 Desember 2018.

Titik Triwulan Tutik, 2011, Konstruksi Hukum Tata Negara Indonesia Pasca Amandemen UUD 1945, Kencana Prenada Media Group, Jakarta.

Titik Triwulan Tutik, 2017, Restorasi Hukum Tata Negara Indonesia Berdasarkan Undangundang Dasar Republik Indonesia 1945, Prenadamedia Group, Jakarta. 